\title{
O narrador de Crime e castigo segundo Gary Rosenshield: o romance polifônico em xeque
}

\author{
Priscila Nascimento Marques ${ }^{1}$
}

\section{O problema do narrador no romance}

O problema do narrador e do ato de narrar remonta a um impreciso e remoto tempo histórico e coloca diante do estudioso questões filosóficas, sociais e literárias que, no limite, dizem respeito à concepção de realidade, de homem e das possibilidades de conhecimento fornecidas pela arte. Na tradição grega, para Platão, a imitação da realidade constituía um simulacro da verdade. Já para Aristóteles, representa uma maneira de revelar sua essência. Tal discussão prossegue ao longo da história e encontra-se intrinsecamente vinculada à reflexão dos diversos gêneros literários.

Considerando que a trajetória do surgimento e desenvolvimento dos gêneros literários relaciona-se com os movimentos sócio-históricos da civilização, verifica-se que o modo pelo qual o homem percebe e representa a si a ao outro sofreu drásticas modificações. Lukács reflete a esse respeito em Teoria do romance, ao abordar as diferenças entre epopeia, tragédia e romance, e estabelecer pontes entre esses gêneros e os contextos em eles se desenvolveram. Bakhtin estabelece, ainda sobre esse assunto, uma importante diferenciação entre epopeia e romance, no que diz respeito ao distanciamento temporal entre o narrador e o narrado. Se "o mundo épico é isolado da contemporaneidade, isto é, do tempo do escritor (do autor e dos seus ouvintes) pela distancia épica absoluta" (BAKHTIN, 1998, p. 405), o romance, por sua vez, "está ligado aos elementos do presente inacabado que não o deixam enrijecer" (BAKHTIN, 1998, p. 417).

O romance surge com a tarefa de dar conta da vivência do indivíduo cuja subjetividade privatizada foi fundada pelo sistema social que se instaura após o fim da Idade Média. A marca constituinte dessa subjetividade é a falta de um referencial fixo e

\footnotetext{
${ }^{1}$ Doutora em Literatura e Cultura Russa pela Faculdade de Filosofia, Letras e Ciências Humanas da Universidade de São Paulo. O presente artigo é derivado da pesquisa de mestrado Polifonia e emoções: um estudo sobre a construção da subjetividade em Crime e castigo de Dostoiévski (MARQUES, 2010), financiada pela Fapesp.
} 
exterior. Tal ruptura com o mundo externo faz com que ele não mais estabeleça parâmetros sobre como pensar, agir e sentir. Paralelamente a essa mudança da experiência, observam-se importantes alterações no modo de narrá-la. A ligação entre narrativa e experiência prática é explorada por Benjamin em seu texto "O narrador". Nele o autor aborda o esfacelamento da função pedagógica da arte, uma vez que esses referenciais, que davam o tom moral das lições que se deve tirar de cada experiência artística, não são mais evidentes:

O romancista segregou-se. O local de nascimento do romance é o indivíduo na sua solidão, que já não consegue exprimir-se exemplarmente sobre seus interesses fundamentais, pois ele mesmo está desorientado e não sabe mais aconselhar. Escrever um romance significa levar o incomensurável ao auge na representação da vida humana. Em meio à plenitude da vida e através da representação dessa plenitude, o romance dá notícia da profunda desorientação de quem vive. (BENJAMIN, 1983, p. 60)

As alterações sofridas pelo fazer narrativo devem-se à introdução desse indivíduo inventado pela modernidade na literatura, conforme observa Ligia Chiappini Moraes Leite:

[...] não se trata mais de falar a um público reunido à sua volta - do qual o aproximam as mesmas experiências e os mesmos valores - aqui, o narrador fala pessoalmente para um leitor também pessoal, individual, numa sociedade dividida (a sociedade de classes). É o fenômeno da particularização em personagens dos antigos heróis universais, coletivamente aceitos como representações de valores comunitários. (LEITE, 2006, p. 11)

Diante dessa ruptura e desorientação, o romance, inicialmente, cumpre o ofício de criar uma realidade. A tipologia de Friedman auxilia a compreender esse processo ao esmiuçar as diferentes formas construção do ponto de vista na narrativa, e, assim, permite compreender como o desenvolvimento da técnica e dos modos de narração se vincula a essas transformações sociais e às demandas delas oriundas, isto é, como a arte passa a recriar a realidade. Em "O ponto de vista na ficção", Friedman cita escritores e teóricos que anunciam o progressivo desaparecimento do autor. A ficção de seu tempo 
(segunda metade do século XX) deflagra a sofisticação dos "melindres", isto é, dos recursos técnicos que possibilitam à história a "contar a si mesma" (cf. expressão de Beach sobre Henry James).

Assim, o romance é marcado pela modalidade do narrador onisciente intruso, na qual "a voz do autor domina o material, falando freqüentemente por meio de um 'eu' ou "nós" (FRIEDMAN, 2002: 173) e em que há intromissões, generalizações autorais sobre a vida e a moral. Dessa forma, a criação da realidade fica a cargo do autor, que incorpora a grande consciência em que tudo está contido, que tudo sabe e compreende, e, por isso, é capaz de elaborar julgamentos morais.

No entanto, como observa Lígia Chiappini Leite, embora esse tipo de narrador fosse comum no século XVIII e início do século XIX, na segunda metade desse século, a literatura dá um passo em direção ao desaparecimento do narrador, pelo predomínio da "neutralidade" naturalista e com a invenção do discurso indireto livre por Flaubert (LEITE, 2006, p. 29). Para Adorno:

O romance tradicional, cuja idéia talvez se encarne de modo mais autêntico em Flaubert, deve ser comparado ao palco italiano do teatro burguês. Essa técnica era uma técnica de ilusão. O narrador ergue uma cortina e o leitor deve participar do que acontece, como se estivesse presente em carne e osso. A subjetividade do narrador se afirma na força que produz essa ilusão e - em Flaubert - na pureza da linguagem que, através da espiritualização, é ao mesmo tempo subtraída do âmbito da empiria, com a qual ela está comprometida.”(ADORNO, 2003: 60)

Tal forma de narrar pressupõe uma consciência ilimitada, e este é o ponto que vai se alterando nas outras formas de narração. O ponto de vista torna-se mais limitado. Na modalidade "Eu" como testemunha o autor abre mão das vantagens não só de sua onisciência, mas também da própria palavra, delegando a narração a um personagem envolvido na trama. Sendo assim ele "escolhe deixar sua testemunha contar ao leitor somente aquilo que ele, como observador, poderia descobrir de maneira legítima" (FRIEDMAN, 2002, p. 176). Semelhante limitação pode ser observada no tipo narrador-protagonista, em que a narração circunscreve-se em um ponto fixo, nesse caso central, da estória. O leitor tem acesso àquilo que o principal personagem sente, vê e pensa por ele mesmo. A seguir, surgem a onisciência seletiva e a onisciência seletiva 
múltipla em que não há uma consciência - a do narrador - se sobrepondo às outras, isto é, não há uma voz exteriorizada e autônoma em relação ao narrado, que o sintetize, julgue, ultrapasse. Predomina o discurso indireto livre, em que se dá o "deslizar do exterior para o interior, encenando o processo mental das personagens" (LEITE, 2006, p. 48). Ocorre a fusão do ponto de vista da personagem e do narrador, que se torna uma espécie de "porta-voz" dos processos mentais do primeiro. Uma radicalização se dá com o modo dramático e a câmera. No primeiro os estados mentais são eliminados tem-se somente a informação daquilo que as personagens falam e fazem. No segundo são transmitidos recortes da realidade de modo arbitrário e mecânico, tal qual uma câmera o faz.

Adorno, ao tratar da distinção entre romance tradicional e moderno, aborda o caráter anti-ilusionista do último, e ilumina a compreensão das transformações sofridas pela narrativa:

[...] no romance moderno [...] a reflexão rompe a pura imanência da forma. Mas essa reflexão, apesar do nome, não tem quase nada a ver coma reflexão pré-flaubertiana. Esta era de ordem moral: uma tomada de partido a favor ou contra determinados personagens do romance. A nova reflexão é uma tomada de partido contra a mentira da representação, e na verdade contra o próprio narrador, que busca, como um atento comentador dos acontecimentos, corrigir sua inevitável perspectiva. A violação da forma é inerente a seu próprio sentido. [...] o autor, com o gesto irônico que revoga seu próprio discurso, exime-se da pretensão de criar algo real, uma pretensão da qual nenhuma de suas palavras pode, entretanto, escapar. (ADORNO, 2003, p. 60)

No final de seu texto Friedman se posiciona em relação à questão do autor, da ficção e da função da arte. Supõe que a extinção do autor, talvez acarrete o desaparecimento da própria ficção, pois

[...] essa arte, por exigir algum grau pelo menos de vividez, também exige, parece-me, uma estrutura, o produto de uma inteligência mentora implícita na narrativa e que dá forma ao material de modo a incitar as expectativas do leitor com relação ao provável curso dos eventos, a cruzar essas expectativas com um curso contrario, igualmente provável e, então, apaziguá-las de maneira que o desfecho resultante pareça, no fim das contas, aquele necessário. [...] Argumentar que a função da literatura é transmitir, 
inalterado, um pedaço da vida é conceber erroneamente a natureza fundamental da própria linguagem: o próprio ato de escrever é um processo de abstração, seleção, omissão e organização.” (FRIEDMAN, 2002, p. 179)

Friedman afirma ainda que a finalidade primordial da ficção é produzir a mais total ilusão possível e que para atingir esse objetivo o escritor deverá recorrer à modalidade narrativa necessária, por uma questão de consistência. Aqui, ecoa mais ou menos claramente a noção aristotélica de verossimilhança, bem como uma concepção positiva de realidade e de ser humano, isto é, parece haver, para Friedman, uma unidade que caracteriza ambos, fato que o leva a acreditar na existência daquela "inteligência mentora implícita". A mesma “des-ilusão" de que sofre Friedman nos idos de 1967, já anunciara Lukács entre 1914 e 15. Para Ligia Chiappini Leite:

Esse ideal de romance, ainda ilustrado, está preso à idéia da coerência, da totalidade e da verossimilhança, e é justamente o que impediu um grande crítico como Lukács de entender o projeto das vanguardas que rompem com a perspectiva coesa do romance do século XIX, porque não crêem mais na sua capacidade de representar uma realidade cada vez menos inteligível, fragmentada e caótica, cujos caminhos de transformação ninguém acredita vislumbrar suficientemente para apontá-los a leitor algum. Ao invés disso, optam por expor o caos, temática e formalmente. (LEITE, 2006, p. 77-8)

É tendo em vista essa condição paradoxal do romance moderno que o presente artigo pretende analisar o narrador de Crime e castigo, de Dostoiévski, a partir da leitura feita por Gary Rosenshield ${ }^{2}$. Inicialmente será feita uma breve exposição das ideias apresentadas pelo crítico no estudo Crime and Punishment: The Techniques of the Omniscient Author ${ }^{3}$, para que essas, num segundo momento, possam ser problematizadas e discutidas, considerando outras abordagens críticas da obra dostoievskiana, mais ou menos congruentes à de Rosenshield.

\footnotetext{
${ }^{2}$ Gary Rosenshield é PhD pela Universidade de Wisconsin-Madison, professor emérito do Departamento de Língua e Literatura Eslavas da mesma universidade. Autor de Western Law, Russian Justice: Dostoesvky e The Jury Trial, and the Law, Pushkin and the Genres of Madness: The Masterpieces of 1833 , entre outros.

${ }^{3}$ A dissertação de mestrado Polifonia e emoções: um estudo sobre a construção da subjetividade em Crime e castigo de Dostoiévski apresenta tradução para o português de três capítulos desse estudo (cf. MARQUES, 2010, p. 267)
} 


\section{2. $O$ estudo de Gary Rosenshield}

Joseph Frank, no capítulo que trata do processo de criação de Crime e castigo, cita o estudo de Gary Rosenshield acerca do narrador neste romance e recomenda-o como uma "análise cuidadosa e perspicaz" e "um dos melhores estudos dedicados ao romance" (FRANK, 2003, p. 125). Victor Terras engrossa o coro elogioso ao afirmar tratar-se de uma "excelente análise" (TERRAS, 1998, p. 63). Com efeito, a leitura Crime and Punishment: The Techniques of the Omniscient Author (1978) revela um estudo consistente e convincente que, além disso, desperta interesse por contrapor-se frontalmente à concepção bakhtiniana de romance polifônico.

Já no prefácio Rosenshield estabelece a importância do estudo do ponto de vista e do propósito do narrador em Crime e castigo como aspectos essenciais da caracterização e do enredo, que propiciam a chave para desvendar os mistérios do epílogo e da personalidade de Raskólnikov (ROSENSHIELD, 1978, p. 06). O estudioso opõe-se ao que afirma ser uma noção difundida, segundo a qual os narradores de Dostoiévski são essencialmente objetivos e cumprem uma função meramente informativa. Em seguida, apresenta sua tese: "Eu pretendo demonstrar que o narrador de Crime e castigo, por muitos meios, alguns sutis e outros óbvios, exerce um papel essencial na estrutura retórica do romance" (ROSENSHIELD, 1978, p. 11). Nesse caso, o ponto de vista do narrador se constitui como um ponto de vista "elevado" cuidadosamente elaborado, ao qual se subordinam todos os elementos do romance, além de funcionar como porta-voz do autor implícito.

Ao definir o narrador como instância portadora de uma consciência superior, que se coloca acima das consciências das outras personagens, Rosenshield retoma a diretriz estabelecida pelo próprio Dostoiévski em seus cadernos de notas para a composição do narrador em questão: "narração do ponto de vista do autor, uma espécie de ser invisível, mas onisciente, que não deixa seu herói por um momento sequer, mesmo com as palavras: 'tudo isso foi feito totalmente por acaso'." (DOSTOEVSKY, 1967, p. 53). O crítico procura demonstrar, contudo, que o narrador não é invisível e que ele abandona seu herói para narrar cenas em que esse não está presente.

Inicialmente, Crime e castigo foi escrito como narrativa em primeira pessoa e sofreu alterações até que Dostoiévski chegasse à forma final em terceira pessoa. 
Rosenshield dedica um capítulo de sua análise a essa mudança de perspectiva no romance, e defende que ela decorre da necessidade de melhor dramatizar o dilema existencial do herói (ROSENSHIELD, 1978: 16). O autor destaca a substancial modificação verificada na passagem da versão inicial (na forma de diário) para a final, conforme o exemplo:

\section{Diário}

Como eu tive força para aquilo! Minhas forças estavam me abandonando tão rapidamente que eu começava a perder a consciência. Relembrando agora em detalhe tudo que aconteceu lá, eu vejo que quase esqueci não somente como eu andei pelas ruas, mas até mesmo por quais ruas. Lembro somente que voltei para casa por um lado totalmente oposto ao de costume. Eu ainda me lembro daquele minuto em que cheguei à V. Prospect, mas depois disso lembro-me de pouca coisa. Como num sonho eu recordo de alguém gritar-me: "Eta porre!". Eu estava provavelmente muito pálido ou cambaleante. (p. 16)

\section{Versão final}

Enquanto isso, sob nenhum pretexto ele se atreveria a aumentar muito o passo, embora estivesse a uns cem passos da próxima esquina. "Não seria o caso de me esgueirar para alguma passagem e ficar esperando por ai em alguma escada desconhecida? Não, a coisa vai mal! E não será o caso de largar o machado em algum lugar? Não será o caso de pegar um coche? A coisa vai mal! Mal!”

Até que enfim um beco; guinou para ele mais morto do que vivo; aí já estava metade salvo, e compreendia isso: menos suspeitas, e ainda por cima um vaivém de gente, e ele desaparecia no meio com um grão de areia. Mas todos esses tormentos o haviam esgotado a tal ponto que ele se movimentava a muito custo. Suava às bicas; tinha o pescoço todo molhado. "Eta porre!" - gritou-lhe alguém, quando ele apareceu no canal. Nesse momento ele se lembrava mal da sua vida; e isso piorava conforme o tempo ia passando. Lembrava-se, entretanto, de que, ao chegar ao canal, levara um súbito susto, de que havia pouca gente e ali estava mais à vista, e quis voltar para o beco. Apesar de quase ter desmaiado, ainda assim deu uma volta e chegou em casa por um lado totalmente oposto ao de costume. (DOSTOIÉVSKI, 2001, p. 99-100) 
Rosenshield atenta para a alteração no foco da atenção na versão final. No diário, Raskólnikov parece separado de seu crime por uma grande distância psicológica e física. O leitor é capturado mais pela condição física e mental do protagonista no momento da escrita do que no momento da fuga. Dostoiévski mostra-se mais preocupado com a psicologia e o comportamento do criminoso depois do crime do que antes ou durante. A recorrência dos verbos "recordar", "lembrar" e "relembrar" leva Rosenshield a acreditar que Crime e castigo era originalmente um estudo psicológico do criminoso após o assassinato: todo o foco parece estar na tentativa de avaliar o significado do passado para a situação presente. Já a versão final enfoca quase exclusivamente o tempo dos eventos, dramatizando a provação psicológica e física de Raskólnikov no maior grau possível. O leitor é transportado para a consciência do herói no momento da fuga. A manutenção do tempo passado dos verbos contribui para o impacto da versão final, pois elimina a mudança abrupta de um plano temporal para o outro. Diferentemente da versão do diário, o tempo passado na versão final é sentido como presente imediato.

Observa-se que, no texto final, Dostoiévski mantém uma passagem de reminiscência, em que Raskólnikov recorda os eventos que estão sendo narrados como presentes. Ao longo do romance, Raskólnikov relembra continuamente eventos que ocorreram antes, durante e depois do crime. Não obstante, a impressão produzida por essas passagens é completamente diferente daquela das reminiscências do diário, pois aqui estão tão sutilmente incorporadas à narrativa, que podem passar despercebidas a um leitor menos atento. Assim, ainda que um exame cuidadoso demonstre que o foco narrativo não se encontra exclusivamente no presente imediato da personagem e no âmbito de sua consciência também presente, a impressão provocada no leitor é a de estar "dentro" da personagem, isto é, vivenciando com ela as experiências atuais. A elaboração formal da técnica narrativa por Dostoiévski o levou a construir um romance exemplar no sentido da representação do fenômeno presente, neste caso a consciência de um dos membros da nova geração. $O$ foco na experiência (e não na recordação) confere fluidez ao texto e envolve emocionalmente o leitor, tornando-o testemunha ocular dos percalços subjetivos, conscientes e inconscientes, de Raskólnikov. Apesar da profunda dramaticidade alcançada pela narração na versão final, Rosenshield argumenta que as passagens de reminiscências são um indício de que o narrador do romance é 
“onisciente e moralmente superior" em relação ao protagonista, e que sua existência é uma das maiores diferenças entre o diário e a versão final (ROSENSHIELD, 1978, p. 21).

Quanto à tipologia, Rosenshield classifica o narrador de Crime e castigo como onisciente seletivo. O ponto de vista de Raskólnikov não é mantido por todo o romance e a transcrição da consciência de outros personagens é atribuída pelo crítico às exigências do enredo. Ressalta ainda que a mudança de foco não compromete o fluxo dos eventos e não tira Raskólnikov do centro da atenção. Rosenshield aponta duas funções para a mudança de perspectiva: 1) espelho: a consciência de outros personagens é transcrita quando se trata da percepção que eles têm de Raskólnikov, o que fornece informações tanto do personagem quanto do protagonista, além de revelar afinidade espiritual entre eles; 2) descrição objetiva: mostrar que determinadas percepções de Raskólnikov não são fruto de seu delírio (ROSENSHIELD, 1978, p. 28).

A visão interior de Lújin, por exemplo, possibilita o estabelecimento de um paralelo entre ele e Raskólnikov no que diz respeito à similaridade entre o orgulho e a confiança exacerbados de ambos. Possibilita ainda a explicitação de pontos em que eles se distanciam, por exemplo, a relação fetichista de Lújin com o dinheiro e o desapego material de Raskólnikov (ROSENSHIELD, 1978, p. 31-4). A visão interior de Svidrigáilov expõe sua falência espiritual e profundo desespero, além de permitir compará-lo e contrastá-lo com Raskólnikov. Esses são os únicos personagens a terem sonhos apresentados no romance, e são eles sonhos que explicitam mais claramente o distanciamento entre ambos, considerando suas profundas diferenças de tom e conteúdo. De um lado, temos os impulsos espontâneos e generosos de Raskólnikov, que apontam para um potencial de regeneração espiritual, de outro, o pesadelo de Svidrigáilov (ROSENSHIELD, 1978, 34-5). Razumíkhin, por sua vez, é apresentado como alternativa prática para Raskólnikov. Prática, pois não é apresentado como símbolo ou tipo psicológico, mas como individuo com profundas raízes na realidade cotidiana. Além disso, a explicitação dos sentimentos de Razumíkhin em relação a Dúnia permite estabelecer paralelos entre eles e outros relacionamentos entre homem e mulher no romance, particularmente o amor lascivo de Svidrigáilov e o amor espiritual de Sônia (ROSENSHIELD, 1978, p. 36-7). 
Rosenshield examina também personagens cujas consciências não são representadas. Porfíri, por exemplo, ocupa uma posição enigmática ao longo de todo o romance, tanto para Raskólnikov quanto para o leitor (ROSENSHIELD, 1978, p. 29). Nos casos de Marmieládov e Catierina Ivánovna a visão interior parece desnecessária, pois ambos expõem seus pensamentos e sentimentos a todo aquele que se dispõe a ouvilos (ROSENSHIELD, 1978, p. 30). Sônia aparece como símbolo de sabedoria intuitiva e fé ilimitada. Constitui-se como personagem alegórica, mais do que psicológica, de modo que sua visão interior, além de supérflua, seria prejudicial (ROSENSHIELD, 1978, p. 30).

A seguir, Rosenshield se debruça sobre as técnicas empregadas por Dostoiévski para representação da consciência. Elenca três delas: 1) monólogo interior; 2) análise mental ${ }^{4}$; 3 ) consciência narrada. Mediante o emprego dessas técnicas, o narrador traduz a vida mental e emocional dos personagens em linguagem literária. Ele estrutura e verbaliza o material frequentemente amorfo e amplamente pré-verbal da consciência (ROSENSHIELD, 1978, p. 38).

O monólogo interior é a forma menos mediada de representação da consciência. Utiliza os tempos e a pessoa do discurso direto e proporciona um sentido de imediatismo e profundidade psicológica, além de impulsionar o enredo e conferir-lha suspense psicológico. Dostoiévski combina o modelo clássico de monólogo - de tom retórico e mais racional, cujo objetivo é desenvolver um raciocínio - com protótipos da forma do fluxo de consciência, com vistas a representar o turbilhão emocional (ROSENSHIELD, 1978, p. 38-48). Por fim, Rosenshield sintetiza as possibilidades e limitações da técnica do monólogo interior afirmando que, se, por um lado, ele permite a individualização do pensamento e do sentimento, conduzindo a níveis mais profundos da consciência, por outro, não viabiliza a combinação de ação, comentário e transcrição de pensamentos e percepções, isto é, a representação da consciência da ação externa, como fazem as técnicas de terceira pessoa (ROSENSHIELD, 1978, p. 49-50).

A técnica da consciência narrada se subdivide em discurso narrado e percepção narrada, e conta com o emprego de palavras, expressões e frases que podem ser facilmente identificadas com um determinado personagem e que se diferenciam

\footnotetext{
${ }^{4}$ Neste trabalho será utilizado o termo análise mental, em preferência à "análise interior" (interior analysis) empregada por Rosenshield, conforme a terminologia de Ligia Chiappini Moraes Leite (2006, p. 66-7).
} 
consideravelmente da prosa do narrador. Por meio dessa técnica é possível ver o mundo exterior pelos os olhos da personagem, ouvir por seus ouvidos e seguir sua sucessão de pensamentos (ROSENSHIELD, 1978, p. 50-3). A análise mental possibilita a apresentação do ponto de vista da personagem, do narrador ou de ambos. Trata-se de uma apresentação menos direta, em que o narrador frequentemente sintetiza a vida interior da personagem e emprega suas próprias palavras para descrevê-la. Tal resumo de processos mentais e emocionais produz menor impacto dramático (ROSENSHIELD, 1978, p. 57-8).

Para Rosenshield, a suavidade com que o narrador desliza de uma técnica a outra, do mundo interior da personagem ao exterior, da ação para a reflexão, de uma temporalidade a outra, faz com que nenhuma brusca interrupção ocorra na representação da consciência. Nas palavras de Rosenshield:

Embora Dostoiévski não tenha escrito romances de fluxo de consciência, sentiu-se compelido por sua visão artística única a fazer uso de todas as técnicas de registro da vida mental a sua disposição. Compreendendo completamente a incomensurabilidade da linguagem literária e da consciência "crua”, Dostoiévski não teve medo de utilizar o narrador para preencher a lacuna entre a realidade da vida da consciência e as exigências de seu leitor, se com isso ele pudesse dar uma visão mais rica e completa daquele mundo psicológico que lhe era característico. (ROSENSHIELD, 1978, p. 61)

Baseado na ideia de que o narrador exerce a função de estruturar a percepção do leitor, governar suas interpretações dos eventos e personagens e sustentar as diretrizes avaliativas do romance, Rosenshield passa à análise dos comentários do narrador. Classifica-os como breves ou longos, e, dentre os primeiros, identifica os seguintes tipos: 1) epíteto avaliativo, como na passagem: "um assassino e uma devassa, que se haviam unido estranhamente durante a leitura do livro eterno"5 (DOSTOIÉVSKI, 2001, p. 339); 2) generalização avaliativa, como em: "Isolara-se decididamente de todos [...]

\footnotetext{
${ }^{5}$ Rosenshield chama atenção para o termo usado no original para referir-se a Sônia (bludnitsa), o qual, em decorrência da sua conotação eclesiástica, liga Sônia a Maria Madalena e não à secular prostitutka. $\mathrm{O}$ epíteto é eficaz ao revelar em uma só palavra o caráter de Sônia como a pecadora moralmente superior, tipo tão caro a Dostoiévski, conforme observa Grossman (1967, p. 45-8). O texto em inglês remete a essa diferença com a utilização dos termos harlot e prostitute. Contudo, a edição em português, de onde foi retirada a citação, não explicita essa conexão. Em verdade, possivelmente ela não seria viável em português, já que o mais apropriado seria utilizar o termo bíblico, que, no caso do português, é "prostituta", de modo que se perde a nuance de significado.
} 
Assim acontece com certos monomaníacos excessivamente compenetrados em alguma coisa" (DOSTOIÉVSKI, 2001, p. 44); 3) palavra ou expressão irônica, como em: "Piotr Pietróvitch Lújin [...] não apareceu, e entretanto ainda ontem à noite Catierina Ivanovna já conseguira dizer a todo mundo, ou seja, a Amália Ivanovna, Pólietchka, Sônia e ao polaquinho, que ele era um homem nobilíssimo" (DOSTOIÉVSKI, 2001, p. 390) e 4) antífrase, como em: "O tenente [...] investiu contra a infeliz da "esplêndida senhora"” (DOSTOIÉVSKI, 2001, p. 112-3). Rosenshield reconhece ainda que tais comentários raramente se referem diretamente a Raskólnikov (ROSENSHIELD, 1978, p. 62-71). Para o crítico, o comentário narrativo longo tem por função representar indiretamente o protagonista (o qual jamais é objeto de tais comentários), isto é, de estabelecer um contraponto a ele (ROSENSHIELD, 1978, p. 83-5). O crítico também se dedica ao exame das descrições físicas das personagens no romance (ROSENSHIELD, 1978, p. 86-98) e as insere na mesma chave de interpretação dos comentários do narrador no que tange à função (crítica implícita a Raskólnikov) e ao efeito no leitor (guia sua percepção).

Como já foi dito, Rosenshield pretende, com sua análise do narrador, apresentar as chaves para a compreensão do epílogo, “de longe o aspecto mais controverso do romance" (ROSENSHIELD, 1978, p. 6). O crítico inicia seu penúltimo capítulo observando que, ao longo de Crime e castigo, não se verifica um desenvolvimento ou mesmo uma mudança do caráter do protagonista, mas a revelação de sua personalidade (ROSENSHIELD, 1978, p. 100). O autor justifica sua posição de que o epílogo está organicamente ligado ao todo do romance a partir de alguns elementos, a seguir elencados. Para ele, a existência de "dois" Raskólnikov (aquele que vivencia os fatos e o que os rememora, e que, portanto, está separado deles pelo tempo e por um novo mundo de experiência) prenuncia o epílogo, ou, ao menos, deixa claro que haverá um Raskólnikov futuro que olhará para os eventos passados de sua vida e os reconsiderará. No conjunto, essas passagens de reminiscências ajudam a responder à pergunta implícita do romance: Qual o destino de Raskólnikov? (ROSENSHIELD, 1978, p. 10611). Além disso, o crítico aponta traços latentes da religiosidade de Raskólnikov: as orações que fazia quando criança, o sentimento inexplicável diante da catedral de São Isaac, a crença expressa na Nova Jerusalém, o desejo inexplicável de ouvir a passagem 
da ressurreição de Lázaro, a necessidade de confessar o crime e a própria confissão (ROSENSHIELD, 1978, p. 111).

Rosenshield rebate a crítica de que epílogo é inverossímil, argumentando que Dostoiévski lança mão de dispositivos estruturais e psicológicos para motivá-lo (ROSENSHIELD, 1978, p. 112-3). Lembra ainda que a função dos epílogos, em geral, é tornar explícito o que no romance propriamente só foi apresentado implicitamente, e que, por isso, difere do restante do texto no tom e na estrutura. Daí a preponderância do sumário na narrativa do epílogo. O tratamento do tempo é drasticamente modificado, se nas seis primeiras partes há presença de marcações temporais precisas, no epílogo somos introduzidos num âmbito temporal especial, que tende mais para as verdades eternas da Bíblia do que para as realidades existenciais da vida pobre da Petersburgo oitocentista. (ROSENSHIELD, 1978, p. 118). Observa-se também a marcante diferença entre o sonho representado no epílogo (revelador do suporte ideológico do romance) e os anteriores (apresentados de modo vívido e detalhado), (ROSENSHIELD, 1978, p. 119). Para Rosenshield, a mudança no tom corresponde à mudança sofrida por Raskólnikov, a qual o crítico ressalta não ser inverossímil e imotivada, dados os traços religiosos latentes do protagonista. Não obstante, Rosenshield faz uma importante consideração: só é possível falar de uma mudança da direção da vida de Raskólnikov, e não numa regeneração completa, ou tampouco conversão. Há uma reconciliação com sua vida emocional, mas não uma aceitação clara da fé ortodoxa (ROSENSHIELD, 1978, p. 120).

No último capítulo, chamado "O ponto de vista elevado", Rosenshield afirma que Crime e castigo deve continuar sendo considerado um dos romances mais objetivos da segunda metade do século XIX e que "o impressionante em Crime e castigo é que Dostoiévski costurou seu narrador tão primorosamente no romance que ele é às vezes negligenciado no conjunto. Somente uma investigação crítica revela que ele de fato carrega todas as funções tradicionais do autor onisciente" (ROSENSHIELD, 1978, p. 125). Por fim, procura responder à seguinte questão: de que decorre a unidade do romance? O cerne de sua resposta está no título do capítulo: tal unidade se deve à construção de um quadro de referência superior ao qual todo o simbolismo, enredo e caracterização estão subordinados: 
O mundo novo e a realidade não sonhada não existem somente no futuro de Raskólnikov, eles são os alicerces de todos os eventos do romance. É uma realidade elevada que é a um tempo transcendente e imanente, e que se revela com força tal somente no epílogo. Não é, contudo, um plano de existência que encontramos frequentemente nos romances do século XIX e isto talvez explique porque tantos críticos consideram falha a representação de Sônia, rejeitaram o epílogo como artisticamente não justificado e ignoraram o trabalho da realidade metafísica. Eles presumiram que Crime e castigo, como qualquer outro romance do século XIX estivesse fundado no mundo dos fenômenos. (ROSENSHIELD, 1978, p. 128)

Rosenshield conclui reconhecendo que a realidade religiosa deve ser aceita como uma força objetivamente existente, que influencia os personagens e, com frequência, oferece-lhes escolhas concretas e significativas. Recorrendo à tipologia dos gêneros de Northrop Frye, o estudioso aponta para as semelhanças que Crime e castigo carrega não só com o romance, mas com a estória romanesca, particularmente no que se refere à caracterização. O romance apresenta-se fortemente fundado na realidade material objetiva, ao passo que "o autor romanesco não tenta criar 'gente real', tanto quanto figuras estilizadas que se ampliam em arquétipos psicológicos, [...] trata da individualidade, com personagens in vácuo idealizadas pelo devaneio" (FRYE, 1973, p. 229). Para Rosenshield, o episódio da leitura da passagem sobre Lázaro da Bíblia indica que o narrador compartilha da fé de Sônia, dada a utilização de linguagem solene e ausência de ironia. Além disso, uma vez que o narrador provou ser confiável em outros momentos do romance, o leitor é compelido aqui a aceitar as verdades bíblicas como válidas não somente para a cena de Lázaro, mas para todo o romance. O leitor suspende sua descrença, pois o ponto de vista do narrador não é, como mantém Bakhtin, apenas uma opinião, mas um ponto de vista elevado que o leitor passa a aceitar e confiar. $\mathrm{O}$ exultante relato da transformação de Raskólnikov e a visão menos crítica das crenças de Sônia asseguram ao leitor que a realidade religiosa é a realidade fundamental. Dessa forma, o narrador onisciente unifica o romance ao subordinar todos os pontos de vista ao seu, e também valida o universo ficcional do qual a relevância máxima desses pontos é derivada (ROSENSHIELD, 1978, p. 131). 


\section{Apontamentos críticos à abordagem de Gary Rosenshield}

Seguindo a exposição das ideias de Rosenshield, procuraremos neste item desenvolver uma breve apreciação crítica de suas teses, no sentido de problematiza-las e enriquecer a leitura do referido romance. Em primeiro lugar, é preciso destacar a relevância do estudo de Rosenshield, pois tal abordagem da estrutura do romance assegura seu estatuto ficcional, ou seja, de construção de uma realidade fundada em princípios estéticos ${ }^{6}$.

A tese-mestre de Rosenshield, segundo a qual o narrador se constitui como ponto de vista elevado, ao qual todos os elementos do romance estariam subordinados, encontra-se em consonância com a interpretação de Frank, para quem há, em Crime e castigo, um narrador autoral, cuja atitude Dostoiévski teria procurado definir com exatidão. O biógrafo ressalta ainda a liberdade de onisciência que o narrador elaborado na versão final manteve, pois, embora esteja estreitamente ligado à consciência do protagonista, ele não perde o controle da perspectiva (FRANK, 2003, p. 138). Rosenshield apresenta evidências suficientes para comprovar sua visão de que narrador e Raskólnikov não podem ser confundidos e que o escopo de suas consciências não coincidem. De fato, são verificáveis passagens em que o narrador relata acontecimentos que o protagonista não presencia, além de apresentar onisciência em relação a outros personagens.

Quanto às observações acerca das mudanças sofridas nas diferentes versões do manuscrito, particularmente a análise acerca da alteração do ponto de vista da primeira para a terceira pessoa, sobressai-se a exposição e o contraste que Rosenshield realiza de excertos de cada uma das versões. O exame da camada linguística do texto transmite consistência à análise e ratifica a conclusão de que, na versão final, o foco narrativo está na experiência da personagem e permite a dramatização de seu dilema existencial. Essas

\footnotetext{
6 "Na medida em que se acentua o valor estético da obra ficcional, o mundo imaginário se enriquece e aprofunda, prendendo o raio de intenção dentro da obra e tornando-se, por sua vez, transparente a planos mais profundos, imanentes à própria obra." (ROSENFELD, 2007, p. 42). A seguinte passagem de Antônio Candido corrobora tal concepção: “[...] a verossimilhança, o sentimento de realidade, depende da unificação do fragmentário, pela organização do contexto. Esta organização constitui o princípio infunde vida aos seres fictícios, os faz parecer mais coesos, mais apreensíveis e atuantes do que os próprios seres vivos." (CANDIDO, 2007, p. 80).
} 
considerações parecem próximas do paralelo que Bakhtin faz entre os personagens dostoievskianos e o do romance de aventura:

[...] não se pode dizer quem é o herói aventuresco. Ele não tem qualidades socialmente típicas e individualmente caracterológicas que possibilitem a formação de uma sólida imagem do seu caráter, tipo ou temperamento [...] Ele também não é substância, mas mera função da aventura [...] O enredo de aventura em Dostoiévski combina-se com uma problematicidade profunda e aguda; além do mais está totalmente a serviço da idéia. Coloca o homem em situações extraordinárias que o revelam e provocam, aproxima-o e o põe em contato com outras pessoas em circunstâncias extraordinárias e inesperadas justamente com a finalidade de experimentar a idéia e o homem de idéia, ou seja, o "homem no homem". Isso permite combinar com aventura gêneros que, pareceria, lhe eram estranhos como a confissão, a vida, etc. (BAKHTIN, 1997, p. 105)

Rosenshield categoriza o narrador de Crime e castigo como onisciente seletivo, e, mais do que isso, aponta os motivos pelos quais a vida interior de outros personagens é representada: função de espelho e descrição objetiva da realidade. Quanto à primeira função, é possível dizer que a necessidade de extrapolar os limites da consciência do protagonista foi a maneira encontrada por Dostoiévski para representar mais completamente essa mesma consciência. Candido afirma que:

O romance, ao abordar as personagens de modo fragmentário, nada mais faz do que retomar, no plano da técnica de caracterização, a maneira fragmentária, insatisfatória, incompleta, com que elaboramos o conhecimento dos nossos semelhantes. Todavia, há uma diferença básica entre uma posição e outra: na vida a visão fragmentária é imanente a nossa própria experiência [...] No romance, ela é criada, é estabelecida e racionalmente dirigida pelo escritor, que delimita e encerra, numa estrutura elaborada, a aventura sem fim que é, na vida, o conhecimento do outro. (CANDIDO, 2007, p. 58)

Assim, o narrador funciona como a instância que dirige essa aventura do conhecimento do outro (o protagonista), e, nesse sentido, parece correta a afirmação de Rosenshield de que o narrador de Crime e castigo opera como porta-voz do autor implícito. O narrador constitui o elo fundador da ficcionalidade do texto, pois por meio das técnicas enumeradas por Rosenshield é capaz de representar a consciência, e atuar 
como tradutor da vida mental e emocional em linguagem literária. Tendo a consciência do indivíduo moderno como objeto de representação, que, além do mais, se pretende realista, Dostoiévski precisou de um narrador não tradicional (conforme Adorno), mas daquele que rompe a distância estética, que "[...] varia como as posições da câmara no cinema: o leitor é ora deixado do lado de fora, ora guiado pelo comentário até o palco, os bastidores e a casa de máquinas" (ADORNO, 2003, p. 61). Ao colocar o indivíduo no centro, tentar defini-lo positivamente, acabá-lo (como parece ser a intenção de Dostoiévski em seu caderno de $\operatorname{notas}^{7}$ ), o autor acabou por representar o "nãoindivíduo" ${ }^{\text {, }}$, isto é, dissolveu-o na consciência dos outros, fragmentou-o, ao ponto em que não se pode dizer quem é, afinal, Raskólnikov, ainda que seja possível afirmar o que ele não é, em contraste o outro. É nesse sentido que Candido reconhece a marcha do romance moderno em direção de uma "complicação crescente da psicologia das personagens, dentro da inevitável simplificação técnica imposta pela necessidade de caracterização" "(CANDIDO, 2007, p. 60). As palavras de Adorno são de grande valor para o entendimento desse ponto:

De fato, os romances que hoje contam, aqueles em que a subjetividade liberada é levada por sua própria força de gravidade a converter-se em seu contrário, assemelham-se a epopéias negativas. São testemunhas de uma condição na qual o individuo liquida a si mesmo, convergindo com a situação pré-individual no modo como esta um dia pareceu endossar o mundo pleno de sentido. (ADORNO, 2003, p. 62)

A compreensão aqui desenvolvida distancia-se da elaboração de Rosenshield num sentido particular, posto que não chega a reconhecer a voz do narrador como uma voz "corporificada", portadora de uma substância própria. Parece-nos mais correto falar

\footnotetext{
${ }^{7}$ [...] a história deve ser narrada pelo autor e não pelo herói. Se deve ser uma confissão, então tudo deve estar claro até o extremo. Cada instante da história deve ser completamente claro. (Total franqueza; completamente sério até o ponto da ingenuidade, e narrar somente o que for necessário). Mas do autor. Muita ingenuidade e franqueza são necessárias. Um narrador onisciente e infalível deve ser adotado; ele deve aparecer como um dos membros da nova geração. (DOSTOEVSKY, 1967, p. 52)

${ }^{8}$ Tomando-se a acepção etimológica: lat. individùus,a,um 'indivisível, uno, que não foi separado"' (cf. Dicionário Houaiss)

${ }^{9}$ É preciso considerar que Dostoiévski lançou mão de técnicas existentes na sua época. Ainda que se fale em antecipação do romance de fluxo de consciência, Rosenshield procura demonstrar que em Dostoiévski não se trata precisamente desta tipologia, mas de um caminho em direção a ela.
} 
desse narrador como função ${ }^{10}$ daquilo que Bakhtin denomina carnavalização, isto é como instância que exerce a função carnavalesca:

A cosmovisão carnavalesca ajuda a Dostoiévski superar o solipsismo tanto ético quanto gnosiológico. Uma pessoa que permanece a sós consigo mesma não pode dar um jeito na vida nem mesmo nas esferas mais profundas e íntimas de sua vida intelectual, não pode passar sem outra consciência. O homem nunca encontrará sua plenitude apenas em si mesmo. (BAKHTIN, 1997, p. 180)

A evidência mais forte que Rosenshield utiliza para atestar sua posição são os comentários do narrador e sua ironia, que constituiriam no conjunto essa voz separada do narrador, esse ponto de vista elevado. A análise de um dos exemplos utilizados por Rosenshield, que figura numa posição central em seu estudo, permite relativizar o poder avaliativo do narrador. Para Rosenshield, a utilização do termo bludnitsa para referir-se a Sônia e associá-la a Maria Madalena, significa que "ele [o narrador] não somente toma o partido de Sônia na luta contra o orgulho demoníaco de Raskólnikov, como também compartilha da fé de Sônia de que Raskólnikov, como Lázaro, pode levantar do mundo dos mortos" (ROSENSHIELD, 1978, p. 64). Dado o contexto da profunda fé de Sônia, de sua pureza moral em contraste com seu trabalho como prostituta (que não macula essa pureza), o epíteto que melhor lhe caracterizaria seria precisamente bludnitsa. De modo que, o narrador não parece estar lançando mão de uma intenção exteriorizante, que define a personagem à sua revelia. $\mathrm{O}$ tom elevado e sagrado é inerente à cena, e não arbitrariamente conferido pelo narrador. $\mathrm{O}$ mesmo pode ser dito sobre o aspecto inusitado da reunião desses personagens e o consequente efeito retórico. Nesse sentido deve ser compreendida toda a linguagem utilizada (bludnitsa, assassino, livro eterno). No entanto, a observação de Rosenshield de que essa passagem prenuncia

\footnotetext{
${ }^{10}$ Ao utilizar o termo função tem-se em vista a noção de "função autor" elaborada por Foucault. Para ele "o autor não é uma fonte infinita de significações que viriam a preencher a obra, o autor não precede as obras. Ele é um certo princípio funcional pelo qual, em nossa cultura, delimita-se, exclui-se ou selecionase: em suma, o princípio pelo qual se entrava a livre circulação, a livre manipulação, a livre composição, decomposição, recomposição da ficção." (FOUCAULT, 2006, p. 288). A subversão do gênero romanesco, e, particularmente, do dito realismo oitocentista, instaurada pela obra de Dostoiévski faz dele "fundador de discursividade", conforme denominação de Foucault, visto que a carnavalização que gerou a obra dostoievskiana produz, para além desta obra, a "possibilidade e a regra de formação de outros textos" (FOUCAULT, 2006, p. 280).
} 
o epílogo, parece acurada, assim como sua tese de que o narrador confere unidade, liga as partes do romance.

O estudioso afirma não haver desenvolvimento do caráter de Raskólnikov em Crime e castigo, o que, como afirma Bakhtin, o distancia do enredo do romance sóciopsicológico, biográfico, familiar e de costumes (1997, p. 104). O resgate do epílogo e sua inserção no todo do romance constitui-se como a grande contribuição do estudo de Rosenshield, pois ele busca alicerçá-lo no conjunto do romance e não identificá-lo como um apêndice dispensável e até mesmo prejudicial ao todo da obra. Nesse sentido, o estudo complementa a fecunda análise de Michael Holquist sobre Crime e castigo, segundo a qual há dois tipos de temporalidade, de enredo e de modos de compreensão da realidade que atuam de forma dialética, construindo a estrutura do romance (HOLQUIST, 1977, p. 75). Para ele, as seis primeiras partes constituem uma complexa variante da história de detetive, em que o objeto da caça e o caçador são a mesma pessoa. O mistério não está na identificação do criminoso, mas dos seus motivos e, para solucionar esse mistério, Raskólnikov lança mão do método histórico, segundo o qual as causas de um fenômeno podem ser racionalmente conhecidas nos seus efeitos:

Uma vez que tudo que é real é, também, racional, e vice-versa [...] a razão será suficiente para chegar-se a uma solução. É a razão que revela a Raskólnikov que ele falhou em sua intenção de transcender a moralidade; portanto, no final do romance acaba por se entregar - ele não é nada além de um criminoso. Seu verdadeiro eu foi descoberto, e assim como a história de detetive, cuja temporalidade ele compartilha, o romance pode, assim, terminar. (HOLQUIST, 1977, p. 92)

No epílogo, por outro lado, uma nova concepção de subjetividade e de temporalidade é apresentada, que melhor corresponde à intenção que leva Raskólnikov ao crime, isto é, a de "criar um kairos secular, um momento que garantiria a validade de todos os outros momentos" (HOLQUIST, 1977, p. 93). Assim, a necessidade do epílogo decorre da ineficácia do método histórico para responder às questões de Raskólnikov. Os eventos finais do romance não tratam de uma nova temporalidade, mas são narrados numa nova temporalidade. Por isso, Holquist identifica o epílogo com a forma do conto (wisdom tale), que, segundo André Jolles, é "uma forma em que o acontecimento e o curso das coisas obedecem a uma ordem tal que satisfaz 
completamente as exigências da moral ingênua" (JOLLES, 1976, p. 200). Nele deve haver, portanto, a subversão da linearidade espaço-temporal da História: "quando o conto adquire traços da História [...] perde uma parte de sua força. A localização histórica e o tempo histórico avizinham-no da realidade imoral e quebram o fascínio do maravilhoso natural e imprescindível” (JOLLES, 1976, p. 202) A verdade não pode ser encontrada no tempo histórico, horizontal, nos efeitos presentes dos eventos passados: "a resposta para tal enigma não é uma solução; mas um lembrete de outro, e maior, mistério" (HOLQUIST, 1977, p. 82, grifo do autor). A tarefa do narrador não consiste em traduzir a consciência de Raskólnikov em linguagem humana. Trata-se, antes, de uma tarefa hermenêutica, de tradução de uma realidade etérea, reveladora de um grande mistério, que não é, e nem poderia ser desenvolvido, explicado. Também nesse sentido não parece adequado falar em ponto de vista elevado, pois elevada é a própria realidade representada (na qual o protagonista se insere), e, assim, o narrador se encontra no mesmo plano de Raskólnikov. De todo modo, Rosenshield foi perspicaz em sublinhar o entrelaçamento desses mundos no romance, como atesta o seguinte excerto:

Ele sofria ao pensar: por que não se matara naquele momento? [...] não conseguia entender que, naquele momento em que estava sobre o rio, talvez pressentisse uma profunda mentira no seu íntimo e sem suas convicções. Não compreendia que aquele pressentimento pudesse ser o prenúncio da futura transformação em sua vida, da sua futura ressurreição, da sua futura concepção de nova vida. (DOSTOIÉVSKI, 2001, p. $554)$.

A passagem revela que há uma potencialidade de transformação no comportamento de Raskólnikov ao longo das seis primeiras partes do romance, mas ela não é explicitada e o narrador não a antecipa. Tanto Holquist quanto Rosenshield reconhecem que os fundamentos de Crime e castigo se encontram numa realidade elevada e não no mundo dos fenômenos. E é esse reconhecimento que pode lançar alguma luz para aquilo que Dostoiévski chamava de realismo num sentido superior. A realidade humana, objeto de representação do autor, não está reduzida aos fenômenos que podem ser racionalmente percebidos, mas tem também ligações com um âmbito inefável, que escapa a quaisquer definições exteriorizantes. O conceito de realidade difundido por Belínksi e seus modos de representação correntes na literatura russa do 
século XIX mostraram-se limitados para dar conta desse novo escopo. Os conceitos de romance polifônico e cosmovisão carnavalesca, desenvolvidos por Bakhtin; a ideia de que Dostoiévski lança mão de materiais heterogêneos, defendida por Leonid Grossman; a forma do wisdom tale, resgatada por Holquist; e, por fim, a estória romanesca, mencionada por Rosenshield, são todas, ao fim e ao cabo, maneiras que tais críticos encontraram para dar conta da novidade apresentada pelo romance dostoievskiano. Ainda que distintas entre si, tais formulações buscam não perder de vista o caráter específico do realismo de Dostoiévski.

Robert Louis Jackson estabelece a diferença entre o conceito de realidade para Belínski e Dostoiévski. O primeiro reconhece a realidade histórica, com suas classes, problemas e conflitos imediatos, com seus tipos sociais e nacionais que expressam a vida e do desenvolvimento da sociedade (JACKSON, 1966, p. 71). Dostoiévski, por sua vez, busca o significado fundamental da existência humana; a realidade, para ele, é o homem, a jornada de sua vida, que é "real, concreta e histórica, mas ao mesmo tempo [...] simbólica, imbuída de uma perspectiva que é transcendental e atemporal" (JACKSON, 1966, p. 71). Assim, o artista não deve simplesmente espelhar a realidade, mas agir sobre ela, "explicá-la" por meio da forma que lhe confere. A atividade criadora é entendida como extrapolação da realidade dada, por meio da atividade propriamente estética, formal. Assim também compreende Grossman:

\begin{abstract}
Um extraordinário faro artístico e a experiência estética segura de romancista sugeriam geralmente a Dostoiévski a lei fundamental e autêntica do retrato: a tipificação da realidade e a transfiguração do fato até a sua expressão criativa, a elevação do caso real até seu enquadramento na lei da concepção artística e a sujeição do instável fenômeno da existência aos princípios sólidos da idéia, da forma e do estilo (GROSSMAN, 1967, p. 73)
\end{abstract}

Em Crime e castigo, observamos esse princípio estruturador da forma precisamente na figura do narrador. É graças a ele que o romance se constitui como um todo, graças a sua atuação como alter ego de Raskólnikov, que não se distancia de seu eixo subjetivo, mas que, para captá-lo, precisa enfocá-lo no âmbito da intersubjetividade. 


\section{Referências Bibliográficas}

ADORNO, Theodor W. Posição do narrador no romance contemporâneo. In: Notas de literatura I. São Paulo: Editora 34, 2003.

BAKHTIN, Mikhail. Epos e Romance. In: Questões de literatura e de estética: A teoria do romance. São Paulo: UNESP/Hucitec, 1998.

BAKHTIN, Mikhail. Problemas da poética de Dostoiévski. Tradução Paulo Bezerra. Rio de Janeiro: Forense Universitária, 1997.

BENJAMIN, Walter. O narrador: Observações sobre a obra de Nikolai Leskow. In: Textos escolhidos. São Paulo: Abril Cultural, 1983. (Coleção Os Pensadores)

CANDIDO, Antonio. A personagem do romance. In: CANDIDO, Antonio. [et. al.]. A personagem de ficção. São Paulo: Perspectiva, 2007. (Coleção Debates, 1)

DOSTOIÉVSKI, Fiódor Mikhailovitch. Crime e castigo. Tradução: Paulo Bezerra. São Paulo: Editora 34, 2001.

DOSTOEVSKY, Fyodor. The Notebooks for Crime and Punishment. Chicago \& London: The University of Chicago Press, 1967.

FOUCAULT, Michel. O que é um autor? In: Estética - Literatura e Pintura, Música e Cinema. Tradução Manoel Barros da Motta. Rio de Janeiro: Forense Universitária, 2006 (Coleção Ditos \& Escritos, 3)

FRANK, Joseph. De novela a romance. In: Dostoiévski: Os anos milagrosos, 1865 1871. São Paulo: Edusp, 2003, 123-141.

FRIEDMAN, Norman. O ponto de vista na ficção: desenvolvimento de um conceito crítico. In: Revista USP. São Paulo, n.53, março/maio 2002.

FRYE, Northrop. Anatomia da crítica. Tradução Péricles Eugênio da Silva Ramos. São Paulo: Cultrix, 1973.

GROSSMAN, Leonid. Dostoiévski artista. Tradução Boris Schnaiderman. Rio de Janeiro: Civilização Brasileira, 1967.

HOLQUIST, Michael. Puzzle and mystery, the narrative poles of knowing: Crime and punishment. In: Dostoevsky \& the novel. Illinois: Northwestern University Press, 1977. JACKSON, Robert Louis. "Reality and its representation in art". In: Dostoevsky's Quest for Form: A Study of His Philosophy of Art. New Haven and London: Yale University Press, 1966. pp. 71-91. 
JOLLES, André. Formas simples: Legenda, saga, mito, advinha, ditado, caso, memorável, conto, chiste. Tradução Álvaro Cabral. São Paulo: Cultrix, 1976.

LEITE, Ligia Maria Chiappini Moraes. O foco narrativo. São Paulo: Ática, 2006.

LUKÁCS, Georg. A teoria do romance: um ensaio histórico-filosófico sobre as formas da grande épica. São Paulo: Editora 34: 2000.

MARQUES, Priscila Nascimento. Polifonia e Emoções: um estudo sobre a construção da subjetividade em Crime e castigo de Dostoiévski. (Dissertação de Mestrado em Literatura e Cultura Russa) Faculdade de Filosofia, Letras e Ciências Humanas, Universidade de São Paulo: São Paulo, 2010.

ROSENFELD, Anatol. Literatura e personagem. In: CANDIDO, Antonio. [et. al.]. A personagem de ficção. São Paulo: Perspectiva, 2007. (Coleção Debates, 1)

ROSENSHIELD, Gary. Crime and Punishment: The Techniques of the Omniscient Author. Lisse: The Peter de Ridder Press, 1978.

TERRAS, Victor. The Art of Crime and Punishment. In: Reading Dostoevsky. Wisconsin: The University of Wisconsin Press, 1998. 